Research Article

www.ijrap.net

\title{
CLINICAL EVALUATION OF AYURVEDIC COMPOUND AND MANUAL DILATATION OF ANUS IN THE MANAGEMENT OF PARIKARTIKA (FISSURE-IN ANO): AN OPEN PERSPECTIVE STUDY
}

Panigrahi Hemanta*

Ayurvedic Central Research Institute, New Delhi, CCRAS, Department of AYUSH, Govt. of India, India

Received on: 11/08/12 Revised on: 20/10/12 Accepted on: 10/11/12

\author{
*Corresponding author \\ E-mail: drhemanta@sify.com \\ DOI: 10.7897/2277-4343.03620 \\ Published by Moksha Publishing House. Website www.mokshaph.com \\ All rights reserved.
}

\section{ABSTRACT}

Parikartika (Anal fissure) is the most common cause of anal pain. The aim of this prospective study was to assess the effectiveness of Ayurvedic compound along with manual dilatation of Anus and Jatyadi tail in anal fissure. 40 patients were included in this study and the therapeutic outcome and side effects were recorded. Recurrence of symptoms occurred in two healed patients in four months. Remission of the disease was found in $80 \%$ of cases which is statistically significant. Partial remission in $12.5 \%$ and no remission was found in $7.5 \%$ of cases. The appetite was markedly improved, which was either nil or, reduced before treatment. The mean was 0.4 as compared to 2.375 before treatment with SD 0.5905 and $\mathrm{P}$ is significant $<0.001$. Complete healing of the fissure occurred in $95 \%$ of the subjects by the end of 30 days ( $<<0.0001$, statistically highly significant). The pain score in the subjects dropped from 3.325 (mean) to 0.35 (mean) in 30days time with SD 0.4830, SEM dropped from 0.1154 to 0.07638 with $\mathrm{P}$ value $<0.001$ which is statistically significant. Ninty nine percent of the subjects experienced a significant fall in the bleeding by the end of 30 days. There was also a significant reduction in the discharge with mean dropped from 3.375 to 0.2 and SD 0.4051 , P value $<0.0001$. Perianal pruritis was also significantly reduced with mean dropped from 3.175 to 0.35 before and after treatment respectively with SD 0.4830 , SEM0.07638, and P value $<0.001$.

Keyword: Vasti netra, parikartika, anulomak, depak, pachak, fissure in ano.

\section{INTRODUCTION}

Anal fissure is a common problem that causes substantial morbidity in people who are otherwise healthy. Incidence of anal fissure is similar in men and women. Spasm of the anal sphincter has been noted in anal fissure, and for many years treatment has been lateral internal sphincterectomy which is simple effective, but the fundamental drawback of surgery is its potential to cause minor but sometimes permanent incontinence in the control of gas, mucus, and occasionally stool ${ }^{1}$. Pharmacological sphincterectomy with injectable botulin toxin and application of nitroglycerin ointment, calcium channel blockers and phosphodiesterase have been used to eliminate the need for surgery and avoid the risk of permanent injury to the internal anal sphincter but have shown to be inconsistent in promoting healing of fissure. However, concerns have been raised about the risk of permanent anal incontinence ${ }^{8}$. Therefore, pharmacological means to treat chronic anal fissures have been explored. In Ayurvedic texts this disease is clinically simulate with Parikartika ${ }^{2}$. However, Sushruta mentioned it as a complication of other disease develops due to mal position of the vasti netra during vasti chikitsa ${ }^{4-7}$. Its treatment in the form of both local and general is well described by Sushruta ${ }^{3}$. The existing present Para surgical methods of treatment are mostly adoptable in large hospitals only, where facilities for conducting major operations are available. The objective of present study is to evaluate the efficacy and applicability of present therapeutic measures which can be practice even in small clinics on O.P.D basis with minimum facilities. In this study, manual dilatation of anus by Lords procedure, Jatyadi tail introduction, and some Ayurvedic drugs has been explored.

\section{MATERIALS AND METHODS}

The study is an analysis of 40 cases of Parikartika (fissure-in-Ano). This study was carried out at Ayurveda Central Research Institute; New Delhi.40 patients with chronic Anal Fissure were enrolled in this prospective clinical study. A written informed consent was obtained from the patients. The treatment protocol was considered to be dishonored if a patient didn't comply with the treatment as he/she was advised. All the drugs were procured from Indian Pharmaceutical Corporation Ltd. Duration of treatment was 30 days.

Institutional Ethical clearance no is F.NO 13-01/2009, ACRI/Tech. Vol III.

Study design: Open level, non comparative, perspective study.

\section{Inclusion criteria}

- Patients who were aged between $\geq 18$ years and $\leq 65$ years

- Suffering from chronic anal fissure for more than 6 weeks

- Physical examination revealed fibrotic anal fissure with indurations at the edges with an external skin tag.

\section{Exclusion criteria}

- History of any reaction to the formulations.

- Associated co-morbidity such as ischemic heart disease, hypertension, diabetes mellitus, anal fistula, hemorrhoids, peri anal abscess, inflammatory bowel disease, tuberculosis ulcer, leukaemic ulcer.

- Pregnant and lactating women.

- Non cooperative patient

- A mentally ill patient. 


\section{Methods of Treatment}

The selected patients were treated as outpatients. They underwent a detailed clinical examination which included a digital and rectal examination. Routine tests of blood like T.L.C., D.L.C., E.S.R, Hb gm \%, and B.T, C.T was done before and after treatment. Routine and microscopic examination of stool was done to ascertain intestinal parasite. Routine and Microscopic Examinations of urine was also done to rule out any specific diseases. They were subjected to the treatment with dilatation of Anus by Lords procedure + Jatyadi tail introduction + Triphala guggulu $500 \mathrm{mg}$ twice daily for 6 consecutive weeks. The subjects were instructed to apply the Jatyadi tail to just inside the anal canal and $1 \mathrm{~cm}$ around the anus by using a disposable van and rubber catheter. The patients were encouraged to eat a high fiber diet and to use warm sitz baths. Manual dilatation of anus was done in lithotomy position. The procedure was performed under local anesthesia with sedatives. Dilatation of anal canal was done up to 4 fingers gradually. Packing of the anal canal was done by Roll bandage. The part was cleaned with medicated swab. After removing the pack $2 \mathrm{ml}$. of jatyadi tail was introduced by means of a rubber catheter and disposable van. T- Bandage was done. The subjects were advised to take Triphala guggulu 500mg twice in a day with lukewarm water.

\section{Follow up and Assessment}

All the subjects were called for follow up at each weekends during the course of the treatment and then bimonthly for a year. The parameters which were recorded at each visit were healing of fissure, pain relief, control of the bleeding, control of the discharge and control of itching. The data was collected and analyzed statistically. The disease was termed as recurrent if either the symptoms and/or the fissure reappeared 1 month after the 30 days course.

\section{Assessment criteria}

Following criteria's are fixed for assessment

\begin{tabular}{|c|c|}
\hline Normal appetite. & 0 \\
\hline Patient has less interest in food but takes food. & 1 \\
\hline $\begin{array}{l}\text { Patients has less interest on food but quantity of intake is } \\
\text { less }\end{array}$ & 2 \\
\hline Patients have no interest on food. & 3 \\
\hline \multicolumn{2}{|l|}{ Table 2: Assessment for constipation } \\
\hline No constipation & 0 \\
\hline Patient passes irregularly hard and soft stool & 1 \\
\hline $\begin{array}{l}\text { Patient passes irregularly hard and soft stool all the time but } \\
\text { does not need laxative }\end{array}$ & 2 \\
\hline Patient needs laxatives to pass stool & 3 \\
\hline Patients need purgative to relive constipation & 4 \\
\hline
\end{tabular}

Table 3: Assessment for pain

Pain was evaluated on visual analogue scale (VAS).

\begin{tabular}{|c|c|}
\hline $\begin{array}{c}\text { Pain at rest, no pain while walking no disturbance in } \\
\text { sleeping }\end{array}$ & 0 \\
\hline $\begin{array}{c}\text { No pain at rest, no disturbance of sleep, mild tolerable pain } \\
\text { while walking }\end{array}$ & 1 \\
\hline $\begin{array}{c}\text { No disturbance of sleep, mild pain at rest, moderate } \\
\text { tolerable pain while walking }\end{array}$ & 2 \\
\hline $\begin{array}{c}\text { Disturbance of sleep due to pain, moderate pain at rest, } \\
\text { severe intolerable pain while walk }\end{array}$ & 3 \\
\hline Sever pain at rest, patients needs medicine for relief & 4 \\
\hline
\end{tabular}

\section{Assessment of Healing}

Healing was assessed by physical examination and subsidence of symptoms like in pain, discharge, Presence of granulation tissue.

Remission: Who had no sign and symptoms or improvement more than $75 \%$.

Partial remission: More than 25\% less than $75 \%$ improvement in clinical features.

No remission: No improvement in clinical feature and other complications not arises

Table 4: Sex distribution in studied case

\begin{tabular}{|c|c|c|c|c|}
\hline Male & $\%$ & Female & $\%$ & Total \\
\hline 25 & 62.5 & 15 & 37.5 & 40 \\
\hline
\end{tabular}

Table 5: Age distribution

\begin{tabular}{|c|c|c|c|c|c|c|c|}
\hline \multicolumn{2}{|c|}{$\begin{array}{c}\text { Below } \\
\text { 20years }\end{array}$} & \multicolumn{2}{|c|}{21 to 40 years } & \multicolumn{2}{c|}{41 to 60 years } & \multicolumn{2}{c|}{$\begin{array}{c}\text { Above } \\
60 \text { years }\end{array}$} \\
\hline Patients & $\%$ & Patients & $\%$ & Patients & $\%$ & Patients & $\%$ \\
\hline Nil & 0 & 23 & 57.49 & 17 & 42.5 & 0 & 0 \\
\hline
\end{tabular}

Table 6: Chronicity in studied case

\begin{tabular}{|c|c|c|c|c|c|c|c|}
\hline \multicolumn{2}{|c|}{$<1$ year } & \multicolumn{2}{|c|}{1 to 3 year } & \multicolumn{2}{|c|}{4 to 6 year } & \multicolumn{2}{|c|}{$>6$ Years } \\
\hline No of pt & $\%$ & No of pt & $\%$ & No of pt & $\%$ & No of $p t$ & $\%$ \\
\hline 32 & 80 & 08 & 20 & 0 & 0 & 0 & 0 \\
\hline
\end{tabular}

Table 7: Position of Fissure in studied cases

\begin{tabular}{|c|c|c|c|c|c|}
\hline Post. mid line & $\%$ & Ant. Midline & $\%$ & Both & $\%$ \\
\hline 35 & 87.5 & 01 & 2.5 & 04 & 10 \\
\hline
\end{tabular}

Table 8: Sphincter tone in studied case

\begin{tabular}{|c|c|c|c|}
\hline \multicolumn{2}{|c|}{ Normo tonic. } & \multicolumn{2}{|c|}{ Hypertonic } \\
\hline No of patients & $\%$ & No of patients & $\%$ \\
\hline 02 & 5 & 38 & 95 \\
\hline
\end{tabular}

Table 9: Result in studied case

\begin{tabular}{|c|c|c|c|c|c|}
\hline \multicolumn{2}{|c|}{ Cured (remission) } & \multicolumn{2}{c|}{ Relived (partial remission) } & \multicolumn{2}{c|}{ No Remission } \\
\hline No. of pts & $\%$ & No. of pts & $\%$ & No. of pts & $\%$ \\
\hline 32 & 80 & 05 & 12.5 & 03 & 7.5 \\
\hline
\end{tabular}

Table 10: Relief in symptoms

\begin{tabular}{|c|c|c|c|c|}
\hline Sign \& symptoms & \multicolumn{2}{|c|}{ Before treatment } & \multicolumn{2}{c|}{ After treatment } \\
\hline & No of pts. & $\%$ & No of pts. & $\%$ \\
\hline Bleeding per rectal & 05 & 12.5 & 0 & 100 \\
\hline Pain during defecation & 40 & 100 & 2 & 5 \\
\hline Mucus discharge & 40 & 100 & 2 & 5 \\
\hline Pruritus Ani & 40 & 100 & 1 & 2.5 \\
\hline
\end{tabular}

Table 11: Statistical Analysis

\begin{tabular}{|c|c|c|c|c|c|}
\hline \multicolumn{2}{|c|}{ Table 11: Statistical Analysis } \\
\hline Symptoms & \multicolumn{2}{|c|}{ Mean } & SD & SEM & P value \\
\hline BT & AT & 0.4830 & 0.07638 & $<0.001$ \\
\hline Pain & 3.325 & 0.35 & & & \\
\hline Appetite & 2.375 & 0.4 & 0.5905 & 0.09337 & $<0.001$ \\
\hline Constipation & 2.9 & 0.5 & 0.6405 & 0.1013 & $<0.001$ \\
\hline Mucus discharge & 3.375 & 0.2 & 0.4051 & 0.06405 & $<0.001$ \\
\hline Pruritus Ani & 3.175 & 0.35 & 0.4830 & 0.07638 & $<0.001$ \\
\hline
\end{tabular}

Table 12: Doshic involvement in studied case

\begin{tabular}{|c|c|c|c|c|c|}
\hline \multicolumn{2}{|c|}{$\begin{array}{c}\text { Vata } \\
\text { dominated }\end{array}$} & \multicolumn{2}{c|}{$\begin{array}{c}\text { Pittaj } \\
\text { dominated }\end{array}$} & \multicolumn{2}{c|}{$\begin{array}{c}\text { Kaphaj } \\
\text { dominated }\end{array}$} \\
\hline No.of pts. & $\%$ & No. of pts. & $\%$ & No. of pts. & $\%$ \\
\hline 31 & 77.5 & 06 & 20 & 03 & 7.5 \\
\hline
\end{tabular}

\section{RESULT AND DISCUSSION}

40 cases of non complicated Fissure in ano patients were selected from the outpatient department of Ayurvedic Central Research Institute, Delhi for the study. All the patients' were kept in a single group. Epidemiology study shows that the disease is prevalent in middle aged and less in old age groups. The person of Vatik and Paittika 
constitution is more prone to this disease. Nature of work and dietary habits is a major causative factor for the disease. Analytical study suggests that intake of low fiber diet, spicy foods; non veg foods are responsible for the disease. Constipation is a chief co-existing factor in the disease followed by irregular bowel habits. Chronicity does not have much significant role in the prognosis. Posterior mid line at 6 o'clock position is the common site for the development of Anal Fissure. However anal fissure can occur in both anterior mid line and in posterior mid line. Most of the female develops Fissure in Ano after child birth. In chronic case of more than one year's skin tag were found. 2 patients having bleeding bright streak of blood in stool and 3 cases were bleeding drop by drop after defecation. Middle income group patients are common sufferer in comparison to higher income group. Business men, those who were having an irregular food intake pattern were prone to this disease. Vata and pitta prakriti persons were more prone to this disease. In 20 to 60 years of age all the patients were found. Patients were having pain in anal region during and after defecation and constipation in common. In $95 \%$ of patients the sphincter tone was hyper tonic. No patients were associated with other systemic disease. The trial medicine was given in traditional vati form, and the oil was prepared according to the principles laid down in Bhaisajya ratnavali. Dose of the Triphala guggulu was $500 \mathrm{mg}$. twice in a day with lukewarm water, and the dose of Jatyadi tail was $2 \mathrm{ml}$ twice daily. Triphala guggulu is depak, pachak and anulomak ${ }^{5}$ and hence stimulate the agni and regulate the bowel. Vasti of Jatyadi tail heals the ulcer and reduces the anal pressure. Manual dilatation of anus regulates the anal sphincter tone. Remission of the disease was found in $80 \%$ of cases which is statistically significant. Partial remission was found in $12.5 \%$ and no remission was found in $7.5 \%$ of cases. The appetite was markedly improved, which was either nil or, reduced before treatment. The mean was 0.4 as compared to 2.375 before treatment with SD 0.5905 and $\mathrm{P}$ is significant $<0.001$. Complete healing of the fissure occurred in $95 \%$ of the subjects by the end of 30days $(\mathrm{P}<0.0001$, statistically highly significant). The pain score in the subjects dropped from 3.325 (mean) to 0.35 (mean) with SD 0.4830, SEM dropped from 0.1154 to 0.07638 with $\mathrm{P}$ value $<0.001$ which is statistically significant. $99 \%$ of the subjects experienced a significant fall in the bleeding by the end of the 30 days. There was also a significant reduction in the discharge with mean dropped from 3.375 to 0.2 and SD 0.4051 , $\mathrm{P}$ value $<0.0001$. Perianal pruritis was also significantly reduced with mean dropped from 3.175 to 0.35 before and after treatment respectively with SD 0.4830 , SEM 0.07638, and $\mathrm{P}$ value $<0.001$.

\section{CONCLUSION}

The treatment with minimum complication and easy applicability should be considered as procedure in the management of Anal Fissure. Observation in present study proves that if different therapeutic measure like Lords procedure, jatyadi tail introduction, along with deepan and anuloman dravya given judiciously, treatment of Fissure in Ano will be better. Advantages of this therapy are its applicability like in small OPD level with minimum facility it can be done. Besides this very minimal recurrence rate and no complications or, side effects occur during this study. So this regimen can be practiced safely.

\section{REFERENCES}

1. Das, Somen, A concise Text book of Surgery. $5^{\text {th }}$ Edition 2008, published by Dr.S.Das oldmayer's court, Kolkata. p $1084-1085$.

2. Bhisag ratna, Kunjalal. The Sushruta samhita, Vol.II, Part-B Published by Cosmo publication Edition2006. p 598.

3. Sushruta, Sushruta Samhita, Edited by Kaviraj Ambikadutta shastri, Published by Chaukhambha Sanskrit sansthan. $8^{\text {th }}$ Edition 1993.Sushuruta chikitsashtan 35/32.Page no.155.Sushruta Chikitsa sthan 34/3page no 147, 34/16, p 151.

4. Charaka, Charaka Samhita, Commented by Kasinath Sastri and Dr.Gorakhnath chaturvedi, Published by Chaukhumba Bharati Academy, Varanasi. Edition, 1991. Charka Siddhi sthan7/56 p1028

5. Charaka, Charaka Samhita, Commented by Kasinath Sastri and Dr.Gorakhnath chaturvedi, Published by Chaukhumba Bharati Academy, Varanasi. Edition, 1991. Charak Siddhi sthan6/61-62 p1041.

6. Singhal, G.D Diagnostic consideration in Ancient Indian Surgery, Pub. By- G.D.Singhal, Allahabad. Edition1972.

7. Sushruta, Sushruta Samhita, Edited by Kaviraj Ambikadutta shastri, Published by Chaukhambha Sanskrit sansthan. $8^{\text {th }}$ Edition 1993, Sushruta Chikitsa sthan36/6 p156

8. Pravin Gupta J. The treatment of fissure in ano- revisited. African Journal of Health Science. 2004;4(1):58-6

\section{Cite this article as:}

Panigrahi, Hemanta. Clinical evaluation of Ayurvedic compound and manual dilatation of anus in the management of Parikartika (fissure-in ano): An open perspective study. Int. J. Res. Ayur. Pharm. 2012; 3(6):792-794 